\title{
AN ANALYSIS OF FEMINISM IN SYLVIA PLATH'S POEMS (THE CONTENT ANALYSIS OF GENERAL MEANING, DETAILED MEANING AND INTENTION)
}

\author{
Indah Damayanti ${ }^{1}$, Hendra $^{2}$, Ina Rohiyatussakinah ${ }^{3}$ \\ Banten Jaya University
}

Indahdamayanti47@gmail.com¹, hendra_cs@yahoo.com², inasakinah1987@gmail.com³

\begin{abstract}
This research is aimed to know meaning and Feminism in Sylvia Plath's Poems. The objectives of this research were to find out the general meaning and detailed meaning and to find out kinds of feminism in poems. This research used qualitative descriptive method using content analysis as the research method. This research used reading and taking note as collecting the data, and technique of analysis data in this research are reading the whole poems, interpreting poems, and making the conclusion. The data source of this research were taken from Sylvia Plath's poems, they are; Daddy, Lady Lazarus, and Last word. The result of this research were findings showed that there were 64 data contained, 59 data in general meaning and detailed meaning in poems and there were 5 data in kinds of feminism in poems. This research concluded the kinds of feminism, they are Liberal Feminism, Radical Feminism, Psychoanalytic Feminism, Marxist Feminism, Socialist Feminism, Multicultural Feminism, Eco feminism, and Postmodern feminism, this research also concluded the kinds of feminism in the poems, they are; poem Daddy (Radical feminism, Marxist feminism, Socialist feminism), poem Lady Lazarus (Marxist feminism), poem Last word (Marxist feminism).
\end{abstract}

\section{Keywords: Meaning, Feminism, Poem}

\section{Introduction}

Most people find difficulties when studying or reading poetry. Any difficult vocabulary in the poems is either explained or given special attention. Poetry is full of meaning and symbol. It is very important to understand about poetry when someone reads poetry. When readers read poetry, they will find meaning of poetry, because poetry have deep meaning. The previous studies above only focused on meaning and feminism. Actually, poetry has several aspects that can be analyzed. Therefore the writer knows clearly the purpose of the poem. The writer chooses 3 poems they are last word, lady lazarus, and daddy. On the basis of the previous studies, in this study the writer intends to
Analyze the poems by focusing on existence of meaning and kinds of feminism in the poems. Meanwhile, the objects of the poems to be studied are different, those of the previous studies.

Poetry is oldest literary works in the history of English literature, several years ago poetry communicated orally of one person to the others. Poetry can be defined as literary work which expression of feeling and ideas that gives intensity by use distinctive style and rhythm, Damanik (2014 : 48).

In this thesis the writer also discuss about meaning, Meaning is what is referred to or indicated by eg sounds, words or signals. Meaning as use refers to 
speaker meaning and particularly the intention of the speaker or the desired communicative effect of the utterance, Mwihaki (2004 : 128).

Next definition about feminism, the term feminism can also be used to describe a political, cultural, or economic movement that is aimed at establishing equal rights and legal protection for women. Feminism involves political, cultural Wiyatmi (2012:10). The reason of appears feminist literature to increase awareness of woman roles in all aspects of literary production as a writer. Feminism combining the doctrine equal rights for a woman that was movement organized to reach woman rights, Humm Humm (2007 : 157-158).

In general, feminism is divided into eight types: they are liberal feminism, radical feminism, marxist and sosialist feminism, psychoanalytic feminism, existential feminism, multicultural feminism, eco feminism, postmodern feminism, Tong (2013: 7-12).

The writer identifies the following problem in the general meaning and detailed meaning about feminist criticism, they are ; To find out how the general meaning and detailed meaning in the Sylvia Plath's Poems discussing about feminism ; To find out kinds of feminism and apply form feminism in Sylvia Plath's poems.

\section{Method of the research}

In this thesis the writer uses library research with qualitative approach to analyze poems. The writer chooses the place in the library, in the classroom, and also in the home.

In this thesis the writers tart on 17th of November, 2017. That time the writer can focus on reading, understanding and analyze the poems.

The writer uses qualitative research, the writer aims to describe the phenomenon will be research. The writer started her research in a situation that exist and describe more deeply. A research usually gathers a lot of data through technique collecting data, for example survey and content analysis.

Content analysis is research technique for making inferences that can be replicated and valid data by considering the context. Some form of classification in content analysis include: pragmatic content analysis, semantic content analysis, and analysis tool sign. Content analysis also can make a replica and valid conclusion from text to the context of their use. Content analysis involves specialized procedures. As a research technique, content analysis provides new insights, increases a researcher understanding of particular phenomena, or informs practical actions, Krippendorff (2013:18). 
In this thesis the writer uses technique content analysis research, the data obtained analysis with qualitative descriptive technique. Read and understand the poems, and after that try to describe general meaning and detailed meaning in the poems.

The writer conducted the analysis through some steps as follow: First reading the whole poems to find some general meaning and detailed meaning identifying in the poem. After that the writer tries to find out the general meaning and detailed meaning of the poems. Second Interpreting poems to find kinds feminism in the poems to identifying the meaning of the poems, the writer reads every words of poems to understand the meaning of the poems. The writer studies the general meaning and detail meaning by identifying word by words to find about some kind feminism. Making conclusion after the writer finds the answer from the research problem, and then the writer makes the conclusion of the analyzed data. And the last the last steps the writer finds the answer from the research problem, and then the writer making the conclusion of the analyzed data.

The writer uses Audit trail in Data Validity, Audit trail is checking back or reviewing data that received before, tracking back all file were collected from a series of research activities, to re- examine the information in poetry that have a general meaning and detailed meaning about feminist in this thesis, obtained during the observations made by checking the correctness of procedures and methods of data collection so that the data obtained valid, Arikunto (26).

\section{Research findings and discussion}

The writer presents the data analysis based on kinds of feminism, general meaning and detailed meaning in Sylvia Plath's poems. The writer analyzed the poems based on Tong's theory. In general, feminism is divided into eight types. They

are liberal feminism, radical feminism, psychoanalytic feminism, Marxist feminism, socialist feminism, multicultural feminism, eco feminism, and postmodern feminism.

In understanding the kinds of feminism data the writer presented explanation that $\mathrm{L}$ as liberal feminism, $\mathrm{R}$ as radical feminism, Pas Psychoanalytic feminism, $\mathrm{M}$ as Marxist feminism, $\mathrm{S}$ as socialist feminism, Muas Multicultural feminism, Ecas Ecofeminism, and Po as Postmodern feminism. And for understanding the general meaning and detailed meaning data the writer presented explanation that $\mathrm{P}$ is poetry, $\mathrm{S}$ is stanza and $\mathrm{L}$ is line of poetry. Its make the writer easier to analyzed the data. 
In this research, there are 104 data which contain general meaning and detailed meaning and kinds of feminism. For general meaning and detailed meaning, the writer found the 99 data they are, in poem "Daddy" there are 50 data, in poem "Lady Lazarus" there are 17 data, in poem "Last Word" there are 32 data. For the kinds of feminism, the writer found the 5 data they are, in poem "Daddy" there are 3 kinds of feminism, in poem "Lady lazarus" only 1 kinds of feminism, in poem "Last Word" there is 1 kinds of feminism.

In this research, the writer only find 3 kinds of feminism in Sylvia Plath's poems, they are Radical feminism, Marxist feminism and Socialist feminism. Radical feminism is a view of the oppression of women which is resulted from a patriarchal system in which women are the principal object of oppression by male's power. Marxist feminism is a more understanding path to gender equality is led by destruction of our capitalist society. And socialist feminism is a theory that emphasizes the aspects of gender and economic classes in the oppression of women.

In daddy poems poem there are 3 kinds of feminism, they are radical feminism, Marxist feminism and socialist feminism. In this poem, Plath give deeply meaning of the story of her daddy. The poem is spoken by a girl with an Electra complex. The father died while she thought he was God. Her case is complicated by the fact that her father was also a Nazi and her mother very possibly part Jewish. In the daughter the two strains marry and paralyze each other, she has to act out the awful little allegory once over before she is free of it.

"Daddy" can also be view as a poem about the individual trapped between herself and society. Plath weaves together patriarchal figures a father, Nazi, a vampire, a husband and then hold them all accountable for history horror. It includes on radical feminism, Marxist feminism and socialist feminism because it describes the individual trapped between herself, society and patriarchal system in which women are the principal object of oppression by male's power ; In last word poems there is 1 kind of feminism, Marxist feminism. This poem is tell about Sylvia Plath was both haunted and mesmerized by death. Suffering from depression at an early age, Plath's poetry deeply encapsulates how she felt about dying. Her depression often evaporated her fear of death.

The poem also focusing on the doom and gloom of dying, her poem "Last Words" imagines death as a grand and gorgeous event. From her opening line, "I do not want a plain box, I want a sarcophagus," she sets the tone for the entire piece as one of celebration. Not only 
she unafraid of her death, she welcomes it warmly. It can be include that poem "Last words" include on Marxist feminism; in lady lazarus poems there is 1 kinds of feminism, Marxist feminism. "Lady Lazarus" is a poem commonly understands about suicide. It is narrated by a woman, and mostly addressed to an unspecified person. Sylvia Plath in Lady Lazarus\| focuses on different elements of her reality and exposes them in her own subjective way, adapted to her own experiences. This dramatic monologue may receive multiple readings based on Sylvia Plath's experiences, namely one may focus on different fragments of her reality and moments of her life. In this way, Sylvia Plath's poem brings together her experiences both as a postmodern artist and as a female poet. It can be conclude that Lady Lazarus poem include to marxist feminism.

\section{Conclusion}

The writer found the meaning in general meaning and detail meaning. First in daddy poem the writer found 50 data second in Last word poems the writer found 17 data; the last in Lady Lazarus poems the writer found 32 data. The writer found 3 kinds feminism in three poems; they are Marxist feminism, radical feminism and socialist feminism. In
Daddy poem the writer found Marxist feminism, radical feminism and socialist feminism, while in poem Last Word the writer only found Marxist feminism, and it is similar with Lady Lazarus poem

\section{References}

Arikunto, Suharsimi. 2006. Prosedur Penelitian Suatu Pendekatan Praktik. Jakarta: PT RinekaCipta.

Damanik, Dara. 2014. Literature. Jakarta: Lingua Pustaka. Krippendorff, Klaus. 2004. Content Analysis: An Introductions to its Methodology (Second Edition), California: Sage Publication.

PDFAlice Mwihaki.Meaning as Use: A Functional View of Semantics and Pragmatics. Tong, Rosemarie. 2009. Feminist Thought. University of North Caroline: Westiview Press.

Wiyatmi. 2012. Kritik Sastra Feminis. Yogyakarta: Penerbit Ombak Dua. 